\title{
Effect of E-Module Stage IV Childbirth Care with Blended Learning Model on Skills Improvement of Midwifery Students
}

\author{
Dwi Ghita \\ Department of Midwifery, Graduate School, Hasanuddin University, Indonesia \\ Corresponding author email: dwighita@pasca.unhas.ac.id \\ Mardiana Ahmad \\ Departement of Midwifery, Graduate School, Hasanuddin University, Indonesia \\ Email: mardiana908@gmail.com

\section{Prastawa Budi} \\ Department of Chemistry, Hasanuddin University, Indonesia \\ Email: prastawa.budi@gmail.com \\ Firda Liantanty \\ Midwifery Undergraduate Study Program Stikes Kurnia Jaya Persada Palopo, Indonesia \\ Email: Liantanty2323@gmail.com

\section{Hamdiah Ahmar} \\ Midwifery Undergraduate Study Program, Mitra Bunda Health Institute, Batam, Indonesia \\ Email: hamdiah@mbp.ac.id
}

\begin{abstract}
Objective: This study aims to determine the effect of education on improving midwifery students' skills in improving management skills for stage IV labor. Methods: This study used a Quasi Experiment (Pre-test post-test design). The population of all students who program the subject of childbirth care is 90 students. The sampling technique was total sampling, then analyzed using the Chisquare and Mann withney. Results: The results of this study indicate that there is a significant effect; the value $(p=0.000, p<0.05)$ improves the skills of D-III midwifery students regarding stage IV delivery care in the Module group and the demonstration method compared to the Module group. Conclusions: Based on the results, the Android-based application of learning mag guru for childbirth improves Midwifery Diploma students' skills in managing stage IV childbirth care.

Keywords---android, learning media, midwifery DIII students, skills, stage IV childbirth care.
\end{abstract}

\section{Introduction}

The vulnerable period in the postpartum period is survival and newborns. Maternal and newborn mortality occurred within the first month after delivery. Therefore, in the management during the vulnerable period, mothers and newborns need to avoid various disorders, especially those related to infections and other diseases. The care for stage IV labor is monitoring the mother's condition 1-2 hours after delivery. Types of childbirth care provided in stage IV monitoring include blood pressure, temperature, pulse, respiration, uterine fundal height, bladder, birth canal laceration, and bleeding (BKKBN, 2017; Oktarina, 2016; Dept. Of Reproductive Health \& Research, 2014).

In fulfilling and achieving learning objectives, students need learning resources as a tool that can be used as a medium for obtaining information in the form of non-printed materials, printed materials, tutorials, interactive videos, pictures, illustrations, animations that stimulate and foster interest and encouragement of students to be more 
active in carrying out teaching and learning activities. Anyone in the learning process can utilize flexible learning resources in different spaces and times, such as independent study at home and group study both by students and lecturers themselves in providing learning (Sari \& Rustana, 2018; Coyne et al., 2018; Blum, 2018).

The use of learning resources is needed to support the teaching and learning process in which there are interacting aspects. Lecturers and students need learning resources and media to get extensive learning opportunities to achieve flexible, efficient, and practical learning goals. However, learning resources are not optimal without paying attention to other aspects of the economic, practical, and relevance of a learning resource development (Abdullah et al., 2019; Hidayat, 2014; Fandianta et al., 2013, Ahmar et al., 2020).

The module is the minor learning program; students study independently or self-instructional and independent learning resources systematically designed to help students achieve their learning goals. According to the Directorate general of improving the quality of educators and education personnel of the national education department (2008), Modules are printed teaching materials that are modified to be studied independently by students. The module is also a medium for independent study because it is equipped with instructions for independent study. The module aims to increase student motivation and enthusiasm for learning. So that students can learn independently and can evaluate learning outcomes, and hone skills in clinical learning. Thus it is hoped that the module will become an option for teachers, instructors, or lecturers in the classroom as a clinical learning medium (Rahdiyanta, 2009; Yaumi, 2018; Jumiyati, 2014).

Clinical learning is one of the processes of educating students in the clinic by the objectives and individual characteristics of students according to the learning concept. Learning steps are essential because they will affect the learning outcomes of students. The learning method itself can be implemented by using learning methods to increase the learning strategy's success (Rizan et al., 2014).

Several health campuses that house Midwifery DIII in the Makassar area show the output of student graduation in practicing midwifery care, especially during stage IV in 2019 from some campuses around $36.6 \%$ who passed the first stage and $63.4 \%$ who have not successfully passed and have to repeat the second stage before being demoted to do practical fieldwork and become a means to hone the skills of midwifery students in facing midwife competency tests (Osca results in data from 3 campuses).

The midwife competency test in Indonesia has only been implemented since 2013 , and the average result of $30 \%$ of participants did not pass the midwife competency test with a pass mark of $40.14 \%$. The list of participants for the midwife competency test from 2017 to 2018 has decreased as follows: 33,792 participants in period IX / 2017, 19,957 participants for period X / 2018, and 13,146 participants in period XI / 2018. The average pass rate for the period is still low, namely 55\% graduation rate (Ristedikti, 2018), and the low pass rate is evident in the midwife competency test period when cracker participated as a test participant, namely period VIII / 2017 was $22.89 \%$, and period X / 2018 is $27.95 \%$ (Fitria et al., 2019).

By looking at the results of competency tests from year to year, especially midwives have more or less illustrated that by holding a competency test, midwives have not been able to achieve the graduation target according to our expectations, so it is necessary to develop learning that can become media Childbirth teacher learning media on stud skills before and after using downloading and using the pre-experimental labor teacher application (One group pretest and post-test design) (Suarsana et al., 2018; Mayer, 2003; Liu et al., 2009). In the first assessment process, a pretest was carried out on students who were learning for students. A student's success to pass the competency test is influenced by several factors that dominate in students, namely interest, motivation, self-confidence, honesty, and thoroughness (Hadina, 2017).

\section{Method}

Data analysis used in this study was based on research data, namely bivariate analysis used to test the hypothesis in this study, chi-square to determine differences in characteristics (family support and motivation) based on variables used the Chi-Square test. To determine the effect of stage IV parenting e-module interventions on students' skill improvement, the Mann-Whitney test was performed.

Researchers used a computerized system of IBM type 25 Statistic Product and Service Solution (SPSS) Program. Data analysis used univariate analysis to determine the frequency distribution and bivariate analysis to determine the effect of the intervention on groups, then the results of the analysis were described in the form of narratives, tables, and diagrams.

The tools and materials used in this study were LCD, laptop, stationery, camera, labor phantom, E-module of stage IV labor care, questionnaires, observation sheets, validated checklist for stage IV labor care. This study's instrument consisted of multiple-choice questions describing the IV stage of labor results taken from an empirical 
case study from the hospital delivery room in South Sulawesi. Validation of questions using expert judgment and level III students of Stikes Nani Hasanuddin Makassar. To assess the questions' legibility, student response questionnaires determine how students respond to the module-based blended learning (BL) model, validated for expert judgment. Then the questionnaire readability test was carried out on 15 students of Stikes Nani Hasanuddin Makassar.

\section{Result}

Analysis Characteristics of DIII Kebidanan Stikes Nani Hasanuddin Makassar

The character of students of DIII Midwifery Stikes Nani Hasanuddin Makassar in this study was analyzed using the Chi-square statistical test with the majority having high learning motivation (72.7\%). Respondents who received family support gave a percentage of $(87.2 \%)$. Meanwhile, respondents who got a GPA> 3.00 got a percentage of $(86 \%)$, then in the age group> 19 years $(63.6 \%)$.

Skills at Stage IV Childbirth Care

Table 1

Skills differences in managing stage IV labor based on learning methods before and after treatment in the intervention group

\begin{tabular}{lcc}
\hline \multicolumn{1}{c}{ Group } & $\mathrm{N}(\%)$ & P Value \\
\hline Demonstration (Control) & $3(10)$ & $0,000 *$ \\
Pretest $(\mathrm{n}=30)$ & $6(20)$ & $0,000 *$ \\
Posttest $(\mathrm{n}=30)$ & & \\
Emodul & $1(3,3)$ & $0,000 *$ \\
Pretest $(\mathrm{n}=30)$ & $21(70)$ & \\
Posttest $(\mathrm{n}=30)$ & $1(3,3)$ & \\
Emodul Demonstration & $28(93,3)$ & \\
Pretest $(\mathrm{n}=30)$ & & \\
Posttest $(\mathrm{n}=30)$ & & \\
\hline
\end{tabular}

*Mann Withney

Table 2

Differences in evaluation skills perform management of stage IV labor based on learning methods before and after treatment in the intervention group

\begin{tabular}{lcc}
\hline \multicolumn{1}{c}{ Group } & N (\%) & P Value \\
\hline Demonstration (Control) & $2(7)$ & $0,000^{*}$ \\
Pretest $(\mathrm{n}=30)$ & $5(17)$ & \\
Posttest $(\mathrm{n}=30)$ & $5(17)$ & $0,000^{*}$ \\
Emodul & $24(80)$ & \\
Pretest $(\mathrm{n}=30)$ & & \\
Posttest (n=30) & $9(30)$ & $0,000^{*}$ \\
Emodul Demonstration & $27(90)$ & \\
Pretest (n=30) & & \\
Posttest $(\mathrm{n}=30)$ & & \\
\hline
\end{tabular}

*Mann Withney 
Table 3

Differences in hygiene and safety skills perform management of stage IV labor based on learning methods before and after treatment in the intervention group

\begin{tabular}{lcc}
\hline \multicolumn{1}{c}{ Group } & $\mathrm{N}(\%)$ & P Value \\
\hline Demonstration (Control) & & \\
Pretest $(\mathrm{n}=30)$ & $10(33,3)$ & $0,000^{*}$ \\
Posttest $(\mathrm{n}=30)$ & $11(36,7)$ & \\
Emodul & $8(26,7)$ & $0,000^{*}$ \\
Pretest $(\mathrm{n}=30)$ & $21(70)$ & \\
Posttest (n=30) & $4(13,3)$ & $0,000^{*}$ \\
Emodul Demonstration & $28(93,3)$ & \\
Pretest (n=30) & & \\
Posttest $(\mathrm{n}=30)$ & & \\
\hline
\end{tabular}

*Mann Withney

\section{Discussion}

The influence of instructional media for childbirth mag guru (Kala IV) with blended learning on student skills

The results of this study indicate that there is an increase in student skills regarding the management of stage IV labor which is significantly marked by a value $(\mathrm{p}=0.000, \mathrm{p}<0.05)$, thus the researchers assume that blended learning is a learning method that combines the provision of E-Modules as an independent learning medium. at home with demonstrations as a laboratory learning at campus can be used to improve student skills, this happens because students are honed in their ability to study independently at home and are strengthened by clinical learning on campus, of course with the application of mag guru labor as a learning medium that can be accessed and studied anywhere and anytime. Given that in the current pandemic, face-to-face learning methods are currently very limited so that the existence of an independent learning application can be a choice for educators to be given to students as students so that they continue to learn actively in this pandemic.

The delivery mag guru application provides an increase in this study seen from the results of the data analysis that it was found that there was a very significant increase from the E-Module group only and the E-Module group and the demonstration (Blended learning), this research was supported by the research conducted (Sulistyawati et al., 2019; Susila \& Iswanto, 2018; Sari \& Rustana, 2018). Blended learning makes students better understand the basic concepts and theories of learning material. Another study found that presenting a simulation video in learning with the blended learning method can provide an overview for nursing students and increase knowledge and attitudes related to child and family care (Chen et al., 2020; Leidl et al., 2020; Coyne et al., 2018).

The results of this study indicate that there is a significant increase in the skills of students in carrying out work procedures for stage IV labor care, with the provision of instructional media for the delivery mag guru application (Yaumi, 2018).

Skills improvement can be seen in Table 2.3 which shows the results that skills in the E-Module group can increase $(70 \%)$ while in the E-Module and demonstration groups also experience a significant increase (93.3\%). Increasing skills by learning using modules is also shown in research Suryati Romauli (2020), that the module can improve nurses' skills in patient safety management.

The skill of implementing postpartum procedures is an action that will affect the patient's condition in a service performed by a midwife to prevent and find out the signs of bleeding. Based on the data that has been obtained, it can be seen that the application of labor mag guru as a learning medium is very helpful for midwife students to improve skills in performing normal delivery assistance.

According to Kim \& Suh (2018), software in the form of a cellphone can be used as an instrument in learning skills. The process of transferring information through applications on smartphones is effective in increasing student knowledge and skills in clinical teaching. Presenting learning videos in training students' skills using media or mobile applications is effective in increasing the skills and self-confidence of students in honing skills independently and having the readiness to be assessed by lecturers (Chuang et al., 2018).

The biggest challenge in the teaching and learning process at this time is the existence of the COVID-19 pandemic so that lecturers as educators must create effective learning media in improving skills and learning 
outcomes, one of which is the learning video presented in the application so that students are independent in learning and hone clinical skills before applying skills in real life (Nik-Ahmad-Zuky et al., 2020).

The blended learning method can be a means of developing independent learning by students in assessing various cases in practical fields according to the speed in understanding and honing skills before being confronted with real patients (Kim et al., 2017). This assumption is reinforced by research Bryan \& Volchenkova (2016), which suggests that blended learning is a learning system of the future where a learning activity creates experiences for students who are accompanied by lecturers as guides or facilitators, either directly or indirectly, to make learning that is more effective, easy to access and use wherever and whenever. Then the use of learning media in the form of applications obtained $77.27 \%$ of the tendency for students to be active in the learning process so that it is said to be effective to use (Sabran \& Sabara, 2019).

\section{Changes in skills in students}

The demonstration method is one of the learning methods used at Stikes Nani Hasanuddin Makassar in the teaching and learning process in the laboratory. This method has been used for a long time, this method is done by showing, demonstrating to students how to perform a clinical action or work procedure in a hospital or in a health service facility. A demonstration is a very important method given to students, especially in clinical learning because it can make it easier for students to master the learning material that has been studied face-to-face in class. With a demonstration, students are allowed to hone their independent skills in providing care to clients. The laboratory is designed in a situation similar to existing health service facilities in the field so that students can hone and apply skills according to the specified competencies (Pangaribuan \& Pratama, 2019).

A learning stage consists of an empirical experience or a practicum process to achieve satisfactory learning outcomes for students compared to face-to-face learning in class. Every clinical learning course focuses on how students can study by what will be faced in the field. The learning process is carried out as a whole which requires transfer, organization, application, and synthesis of the previously learned people (Mansyur et al., 2017).

The skills of students in this study before the intervention in stage IV childbirth care procedures showed that there was no significant change in the three groups before being given treatment, in this case, the demonstration (control) group, E-Module, E-Module, and demonstration of students' skills. After the treatment was carried out in each group except the control group, in the E-Module group after being given treatment in the form of a labor mag guru application containing E-Modules, quizzes, and learning videos for stage IV labor management, E-Module as one of the learning media that has attractiveness and can increase the learning motivation of students who can use it independently and anywhere (Saputra \& Lisiswanti, 2019). Students are said to be ready to carry out clinical learning in the laboratory when practicing confidently because they have studied the E-Module given previously (Hansen et al., 2019).

Independent learning with applications/software in the operating system where students can access learning material anywhere and anytime and can evaluate their abilities independently before making face-to-face meetings with educators (Irawan \& Tandyonomanu, 2016). The blended learning method is effective in various aspects, including improving learning outcomes, curiosity/motivation so that students are more active in finding the concept of learning material to be achieved (Muazizah et al., 2019). Demonstration learning methods that have been considered attractive clinical learning strategies combined with the provision of learning applications containing modules are able to increase skills in student (Efgivia, 2019; Haksara \& Rahmanti, 2019).

Based on tables 3.2, 3.3, and 3.4, it shows that the skills of STIKES student Nani Hasanuddin, Diploma III midwifery study program of midwifery in the third semester of stage IV childbirth management experienced a significant increase in skills, namely in the E-Module group and demonstrations. Skills in performing postpartum procedures (93.3\%) of skilled students, then the skills of conducting postal evaluation (90\%) of skilled students, while the skills in maintaining cleanliness and safety after childbirth were obtained (93.3\%) skilled students. A significant increase can be seen in tables 2.1,2.2, and 2.3 of the results of the data analysis above.

The results of research conducted by Sanjaya (2019), show that the blended learning method is able to increase knowledge and skills on clinical competence as measured by the clinical competency questionnaire (KKK). The average pretest score in each group is still low, this can be interpreted that students' initial abilities cannot be said to be good. With blended learning, students are able to apply theory and empirical experience in the laboratory so as to successfully improve affective, cognitive, and psychomotor which are reflected in critical thinking and behavior (Rohendi et al., 2020). 


\section{Conclusion}

Learning media for delivery mag guru can significantly influence the learning skills of Midwifery DIII students if it is combined with conventional demonstration learning methods in managing the IV stage of labor. For further researchers, a deeper study is needed on the effectiveness of using online learning media for the 3 components of learning outcomes for midwifery students. It is expected that using multivariate analysis than looking at what factors affect the knowledge and skills of midwifery students.

\section{Acknowledgments}

Our gratitude goes to all those who played a role in making this research. Thank you to the Director of Stikes Nani Hasanuddin Makassar and the Chair of the Midwifery DIII study program for providing permission and information so that this research can be researched properly and Thank you to all respondents who took the time to answer the research questionnaire so that the results in this study were obtained.

\section{References}

Abdullah, M. Y., Al Ghafri, H. M. H., \& Al Yahyai, K. S. H. (2019). A Qualitative Study on the Best Motivational Teaching Strategies in the Context of Oman: Perspectives of EFL Teachers. English Language Teaching, 12(3), 57-64.

Ahmar, H., Budi, P., Ahmad, M., Mustary, M., \& Hutagaol, I. O. (2020). The Influence of Problem Based Learning Model Based on Midwifery First Stage of Childbirth Care Module in Improving Learning Quality. International Journal of Psychosocial Rehabilitation, 24(2).

BKKBN, B. (2017). Kemenkes, \& USAID.(2017). Survey Demografi dan Kesehatan Indonesia. Survei Demografi dan Kesehatan Indonesia.

Blum, A. (2018). Plant breeding for stress environments. CRC press.

Bryan, A., \& Volchenkova, K. N. (2016). Blended learning: definition, models, implications for higher education. Bulletin of the South Ural State University. Series: Education. Pedagogical Sciences, 8 (2).

Chen, N., Zhou, M., Dong, X., Qu, J., Gong, F., Han, Y., ... \& Zhang, L. (2020). Epidemiological and clinical characteristics of 99 cases of 2019 novel coronavirus pneumonia in Wuhan, China: a descriptive study. The lancet, 395(10223), 507-513. https://doi.org/10.1016/S0140-6736(20)30211-7

Chuang, Y. H., Lai, F. C., Chang, C. C., \& Wan, H. T. (2018). Effects of a skill demonstration video delivered by smartphone on facilitating nursing students' skill competencies and self-confidence: A randomized controlled trial study. Nurse education today, 66, 63-68. https://doi.org/10.1016/j.nedt.2018.03.027

Coyne, E., Frommolt, V., Rands, H., Kain, V., \& Mitchell, M. (2018). Simulation videos presented in a blended learning platform to improve Australian nursing students' knowledge of family assessment. Nurse education today, 66, 96-102. https://doi.org/10.1016/j.nedt.2018.04.012

Efgivia, M. G. (2019). Pengaruh Media Blanded Dan E-Learning Terhadap Hasil Belajar Mahasiswa Pengembangan Media Audio Mahasiswa Semester IV TP UIKA Bogor. Educate: Jurnal Teknologi Pendidikan, 4(2), 85-96.

Fandianta, F., Sanjaya, G. Y., \& Widyandana, W. (2013). Fleksibilitas Belajar Mengajar Melalui Metode Blended Learning. Jurnal Pendidikan Kedokteran Indonesia: The Indonesian Journal of Medical Education, 2(2), 146153.

Fitria, R., Serudji, J., \& Evareny, L. (2019). Persiapan Uji Kompetensi Bidan sebagai Exit Exam. Jurnal Ilmiah Universitas Batanghari Jambi, 19(1), 195-203.

Hadina, D. (2017). Faktor Diri Mahasiswa yang Memengaruhi Kelulusan Uji Kompetensi D III Kebidanan di Poltekkes Kemenkes Palu. Jurnal iImu Kesehatan, 1(22), 1120-1131.

Haksara, E., \& Rahmanti, A. (2019). Implementasi New Preceptorship Development Program for Patient Safety terhadap Peningkatan Mutu dan Keselamatan Pasien. Jurnal Ilmiah Kesehatan, 12(1).

Hansen, J. R., Gefke, M., Hemmingsen, R., Fog-Petersen, C., Høegh, E. B., Wang, A., \& Arnfred, S. M. (2019). E-library of authentic patient videos improves medical students' mental status examination. Academic Psychiatry, 1-4.

Hidayat, W. (2014). The Implementation of MEAs Instruction to Students' Mathematics Problem Solving and Connecting Ability. In Proceeding of International Conference On Research, Implementation, And Education Of Mathematics And Sciences (pp. 18-20).

Irawan, F. C., \& Tandyonomanu, D. (2016). Pengembangan E-Module Berbasis Android untuk Mata Pelajaran Manajemen Produksi pada Siswa Kelas XI. J. Mhs. Teknol. Pendidik, 1(1), 0-216.

Jumiyati, J. (2014). Pengaruh pelatihan metode simulasi terhadap perilaku kader dalam upaya pemberian asi eksklusif. JURNAL MEDIA KESEHATAN, 7(1), 06-12. 
Kim, H. S., Kim, M. Y., Cho, M. K., \& Jang, S. J. (2017). Effectiveness of applying flipped learning to clinical nursing practicums for nursing students in Korea: a randomized controlled trial. International journal of nursing practice, 23(5), e12574.

Kim, H., \& Suh, E. E. (2018). The effects of an interactive nursing skills mobile application on nursing students' knowledge, self-efficacy, and skills performance: A randomized controlled trial. Asian Nursing Research, 12(1), 17-25. https://doi.org/10.1016/j.anr.2018.01.001

Leidl, D. M., Ritchie, L., \& Moslemi, N. (2020). Blended learning in undergraduate nursing education-A scoping review. Nurse education today, 86, 104318. https://doi.org/10.1016/j.nedt.2019.104318

Liu, S. H., Liao, H. L., \& Pratt, J. A. (2009). Impact of media richness and flow on e-learning technology acceptance. Computers \& Education, 52(3), 599-607. https://doi.org/10.1016/j.compedu.2008.11.002

Mansyur, A., Gunawan, A., \& Munandar, A. (2017, October). Study on ecological design concept of Buton sultanate cityscape based on local culture. In IOP Conference Series: Earth and Environmental Science (Vol. 91, No. 1, p. 012021). IOP Publishing.

Mayer, R. E. (2003). The promise of multimedia learning: using the same instructional design methods across different media. Learning and instruction, 13(2), 125-139. https://doi.org/10.1016/S0959-4752(02)00016-6

Muazizah, N. M., Nurhayati, S. and Cahyono, E. (2019) 'Berpendekatan Guided Inquiry Terhadap Hasil Belajar Siswa', Jurnal Inovasi Pendidikan Kimia, 10(2), p. 1760.

Nik-Ahmad-Zuky, N. L., Baharuddin, K. A., \& Rahim, A. F. A. (2020). Online Clinical Teaching and Learning for Medical Undergraduates during the COVID-19 Pandemic: The Universiti Sains Malaysia (USM) Experience. Education in Medicine Journal, 12(2), 75-80.

Oktarina, E. (2016). Aplikasi modern wound care pada perawatan luka infeksi di RS Pemerintah Kota Padang. Ners Jurnal Keperawatan, 12(2), 159-165.

Pangaribuan, R., \& Pratama, M. Y. (2019). Keperawatan Kegawatdaruratan Di Akademi Keperawatan Kesdam I / $\mathrm{Bb}$ Medan Medan Method of Simulation and Demonstration Learning in Laboratory With Emergency Learning Outcomes in Nursing Academy of Kesdam I / BB Medan. 1(2), 128-132.

Rahdiyanta, D. (2009). Kurikulum Berbasis Kompetensi (KBK)(Pengertian dan Konsep KBK). In Seminar Nasional Implementasi KBK di PT-UNY, Agustus 2003Wina Sanjaya, Perencanaan dan Desain Sistem Pembelajaran. Jakarta: Kencana.

Rizan, M., Warokka, A., \& Listyawati, D. (2014). Relationship marketing and customer loyalty: do customer satisfaction and customer trust really serve as intervening variables?. Journal of Marketing Research \& Case Studies, 2014, 1.

Rohendi, H., Ujeng, U., \& Mulyati, L. (2020). Pengembangan Model Blended Learning Dalam Meningkatkan Learning Outcome Mahasiswa Di Lahan Praktik Klinik Keperawatan. Jurnal Ilmu Kesehatan Bhakti Husada: Health Sciences Journal, 11(2), 336-350.

Sabran, S., \& Sabara, E. (2019, February). Keefektifan Google Classroom sebagai media pembelajaran. In Seminar Nasional LP2M UNM.

Sanjaya, G. Y. (2019) 'Memberikan Fleksibilitas Belajar Mengajar Melalui', Jurnal Pendidikan Kedokteran Indonesia, 2(2), 1-8.

Sari, L. Q., Rustana, C. E., \& Raihanati, R. (2018, October). Pengembangan E-Module Menggunakan Problem Based Learning Pada Pokok Bahasan Fluida Dinamis Guna Meningkatkan Hasil Belajar Kognitif Peserta Didik Sma Kelas XI. In Prosiding Seminar Nasional Fisika (E-Journal) (Vol. 7, pp. SNF2018-PE).

Suarsana, I. M., Mahayukti, G. A., Sudarma, I. K., \& Yoga, I. N. B. A. (2018). Development of interactive mathematics learning media on statistics topic for hearing-impaired student. International Research Journal of Engineering, IT and Scientific Research, 4(6), 55-66.

Sulistyawati, S., Dwi Astuti, F., Rahmah Umniyati, S., Tunggul Satoto, T. B., Lazuardi, L., Nilsson, M., ... \& Holmner, A. (2019). Dengue vector control through community empowerment: lessons learned from a community-based study in Yogyakarta, Indonesia. International journal of environmental research and public health, 16(6), 1013.

Suryati Romauli, Y. M. W. (2020) 'Jurnal keperawatan tropis papua’, Jurnal Poltekkes Jayapura, 01(September), 16.

Susila, A. B., \& Iswanto, B. H. (2018, November). Pengembangan Media Pembelajaran Video Tutorial Berbasis Web Untuk Materi Gelombang Bunyi Di SMA. In Prosiding Seminar Nasional Fisika (E-Journal) (Vol. 7, pp. SNF2018-PE).

Yaumi, M. (2018). Media dan teknologi pembelajaran. Prenada Media. 